\title{
Morphometric Characterization and Seed Dormancy Overcoming of Sapindus saponaria $\mathrm{L}$.
}

\author{
Maria Inajal R. S. das Neves ${ }^{1}$, João C. de Araújo Neto ${ }^{1}$, Vilma M. Ferreira ${ }^{1}$, Clissia B. da Silva ${ }^{1}$, \\ João L. A. Melo Júnior ${ }^{1}$, Luan D. F. A. Melo ${ }^{1}$, Aristeia S. Farias ${ }^{1}$, Elaine R. Galvão ${ }^{2}$ \& Vinicius S. G. da Silva ${ }^{1}$ \\ ${ }^{1}$ Center of Agricultural Sciences, Federal University of Alagoas, Rio Largo, Brazil \\ ${ }^{2}$ Bahia State University, Juazeiro, Bahia \\ Correspondence: Vinicius S. G. da Silva, Center of Agricultural Sciences, Federal University of Alagoas, Rio \\ Largo, Alagoas, Brazil. Tel: 55-82-3214-1317. E-mail: vinicius.agro2008.1@gmail.com
}

Received: March 28, 2018

Accepted: May 1, $2018 \quad$ Online Published: June 15, 2018

doi:10.5539/jas.v10n7p329

URL: https://doi.org/10.5539/jas.v10n7p329

\begin{abstract}
S. saponaria L. is a Brazilian native arboreal species, with relevant ecological importance in the recovery of degraded and marginal areas. The objectives of the present study were to characterize morphometrically Sapindus saponaria L. seeds, to extract and to quantify oil content, establish the percent composition of fatty acids; to describe their different post-seminal stages; to describe the different post-seminal stages, as well as to evaluate the germinative performance of the seeds as a function of different treatments to overcome dormancy. Seeds were evaluated as to water content and biometric length and width. The extraction and quantification of the seed oil was obtained by the solvent extraction method using the Soxhlet extractor system. Regarding the post-seminal development, some processes triggered during growth and development of the seedlings were evaluated. The treatments for dormancy overcoming were: mechanical scarification, chemical scarification with sulfuric acid for $5,10,20,30$ and 40 minutes, immersion in hot water $\left(80^{\circ} \mathrm{C}\right)$ until reaching room temperature, immersion in distilled water at room temperature for 24 hours and intact seeds (control). The seeds were evaluated for germination, velocity, medium time, synchrony and germination uncertainty. The design was a completely randomized design with four replicates of 25 seeds per treatment. The seeds present on average 10.3 $\mathrm{mm}$ in length and $10.2 \mathrm{~mm}$ in width with hygene-cryptocoledonar germination. The oil content found in the seeds was $7.25 \%$, most of which was composed of unsaturated fatty acids (78.9\%). The highest values of germination occur when the seeds are immersed in sulfuric acid for 30 minutes.
\end{abstract}

Keywords: forest species, germination, post-seminal, seedling.

\section{Introduction}

The search for forest species with potential to recovery degraded areas and for afforestation has increased in recent years. However, there is no information available on the management of most seeds of native species, which are basic inputs for ecosystem recovery and conservation projects. Therefore, there is a need for research aimed to determinate the basic information for the proper management of its seeds.

The forestry sector contributes significantly to the Brazilian economy by obtaining products for export or domestic consumption, generating employment for the population, as well as contributing to the conservation and preservation of renewable natural resources (Ladeira, 2002). Although there is a large number of native species traded in Brazil for forest recomposition, few are described in the Rules for Seed Analysis (Brasil, 2009). According to Sarmento and Villela (2010), more research is needed with native tree seeds, especially regarding the physiological aspects involved in germination.

S. saponaria L., is a native, arboreal species and popularly known as soapwort, with relevant ecological importance in the recovery of degraded and marginal areas, that allow the reconstruction of the complex interactions existing within a community, as well as its local self-perpetuation. The demand for seeds and fruits of this species also has increased in recent years due to its use as an ornamental plant, its dense and globulous crown, medicinal properties, with roots and barks with calming, astringent, antispasmodic and antitussive substances. The fruits are rich in saponin, a natural surfactant, which can be used as soap (Ribeiro et al., 1999; Judd et al., 2009) and used for ulcers treatment, inflammations and skin lesions (Pelegrini et al., 2008). In 
addition, they have several insecticidal and sarnicidal properties such as: tannin, fatty acids, triterpenes, anthocyanin, unsaturated steroids, rutin, luteolin, amirin and sitosterol (Previero et al., 2010; Souza \& Lorenzi, 2012; Mena-Valdés et al., 2015). Its wood is heavy, hard and compact, used in construction and in the making of toys (Pio-Correa, 1984; Lorenzi, 1992).

S. saponaria L. species, has little information to analyze its seeds, being necessary to obtain information on germination aspects, allowing its use for a wide variety of purposes, as well as offering support to a wide variety of reforestation programs. In this context, the objective of the present work was to characterize the morphometrically of $S$. saponaria seeds, to describe the different post-seminal stages, as well as to evaluate their germinative performance as a function of different treatments of dormancy overcoming.

\section{Material and Methods}

\subsection{Local and Execution Period}

The tests were conducted at the Plant Propagation Laboratory of the Center of Agricultural Sciences (CECA) of the Federal University of Alagoas (UFAL), located in the municipality of Rio Largo, state of Alagoas, Brazil. $S$. saponaria seeds were harvested from trees located in the municipality of Maceió, state of Alagoas, at $9^{\circ} 37^{\prime} 40.90^{\prime \prime}$ latitude and $35^{\circ} 44^{\prime} 18.13^{\prime \prime}$ longitude, with an altitude of $59 \mathrm{~m}$ in December 2014.

\subsubsection{Assay 1: Morphometric Characterization of Seeds}

For physical characterization, length $(\mathrm{mm})$ and width $(\mathrm{mm})$ were determined using a precision digital pachymeter of $0.1 \mathrm{~mm}$ using eight replicates of 100 seeds. The length was determined from the base to the apex (Figure 1A) and the width measured at the median line of the seeds (Figure 1B). For each variable, mean, modo, median, amplitude of variation, variance, standard deviation and coefficient of variation were calculated (Banzato \& Kronka, 1992; Melo et al., 2015).

For the internal morphological observations (embryo and reserve tissue), the seeds were previously immersed in distilled water for 24 hours at $30{ }^{\circ} \mathrm{C}$ for softening and hydration. After this period, they were cut longitudinally with a blade and then observed in a magnifying glass.

Seed length and width data were grouped into class for better presentation on the frequency histogram. In order to indicate the degree of distortion of the distribution in relation to a symmetrical distribution, the asymmetry coefficient of Persons (1910) was calculated.

The weight of 1,000 seeds was determined using eight replicates of 100 seeds, and the mean, standard deviation and coefficient of variation were calculated (Brasil, 2009). The extraction and quantification of the oil was performed according to the methodology of Oliveira et al. (2009) using the Soxhlet extractor system, with hexane solvent.

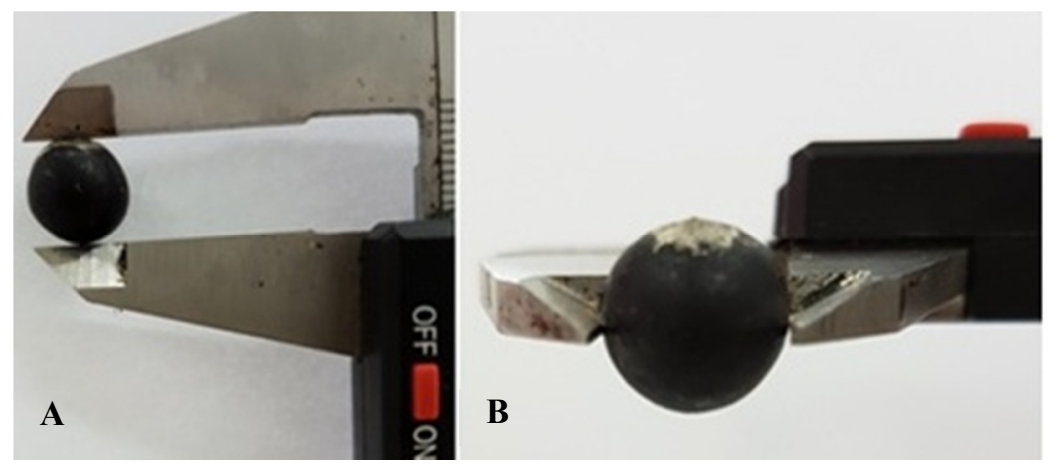

Figure 1. Length (A) and width (B) measurement of seeds of Sapindus saponaria L.

\subsubsection{Assay 2: Post-seedling Development of Seedlings}

The follow-up and registration of the different stages of post-seminal development were performed according to Oliveira (1993). In this study, the different stages of seedling development were observed daily. Abnormalities occurred in the seedlings, as well as the type of germination of the species in question, were also evaluated. For this, four replicates of 25 seeds were distributed over two sheets of paper towel, moistened with distilled water 
equivalent to 2.5 times the dry weight of the paper, and covered by a third sheet. Afterwards, rolls were formed, and these were packed in a germinator regulated at a temperature of $30{ }^{\circ} \mathrm{C}$ under constant light.

\subsubsection{Assay 3: Treatments for Overcoming Numbness}

The seeds were previously submitted to asepsis, performed by immersion in $70 \%$ alcohol, for one minute, with subsequent washing in distilled water. The following treatments were performed:

$>$ Mechanical scarification using sandpaper number 6, rubbing the integument on the side opposite the micropyle;

$>$ Chemical scarification by immersing the seeds in concentrated sulfuric acid (98\%) for different periods (5, $10,20,30$ and 40 minutes), followed by washing under water;

$>$ Immersion in hot water $\left(80^{\circ} \mathrm{C}\right)$ until water reaches room temperature;

$>$ Immersion in distilled water (room temperature) for 24 hours;

$>$ Control (intact seeds).

To evaluate the efficiency of the pre-germination treatments, the germination test was carried out with four replicates of 25 seeds. The seeds were distributed on two sheets of paper towel, previously moistened with distilled water in the proportion of 2.5 times the weight of the dry paper and kept in a germination chamber regulated at $30{ }^{\circ} \mathrm{C}$ (Camara et al., 2009).

The trials were conducted in a completely randomized design with four replicates of 25 seeds. The data were submitted to analysis of variance (ANOVA). For the biometric assays, a descriptive analysis of the data was performed. The averages were compared by the Tukey test at 5\% probability, and for the germination percentage, the data were transformed into arcsen $\sqrt{\mathrm{x} / 100}$, according to Banzatto and Kronka (1992).

\section{Results and Discussion}

\subsection{Physical Characterization of Sapindus saponaria L. Seed}

The water content of S. saponaria seeds was $17 \%$. The values of length and width presented an average of 10.3 $\mathrm{mm}$ and $10.2 \mathrm{~mm}$, respectively. With a small amplitude of variation of approximately $1.4 \mathrm{~mm}$ for length and 1.5 $\mathrm{mm}$ for width (Table 1).

The biometric characterization of seeds allows to identify genetic variations within populations of the same species or differentiating species of the same genus from environmental factors (Gusmão et al., 2006; Virgens et al., 2016), besides being directly associated with as well as to determine seed dispersal and establishment of seedlings, thus making it possible to differentiate between pioneer species and climax in tropical forests (Cruz et al., 2001; Matheus \& Lopes, 2007). Although biometric characteristics of seeds can be taxonomically questionable, due to the strong influence of latitudinal, seasonal and microclimatic variations, they have great biological significance, related to dispersing agents and dispersion syndromes (Rodrigues et al., 2006).

Table 1. Descriptive analysis of seed length and width of Sapindus saponaria L.

\begin{tabular}{lll}
\hline Statistical measures & Length $(\mathrm{mm})$ & Width $(\mathrm{mm})$ \\
\hline Average & 10.3 & 10.2 \\
Modo & 10.3 & 10.3 \\
Medium & 10.4 & 10.0 \\
Minimum & 9.4 & 9.2 \\
Maximum & 10.8 & 10.7 \\
Standard deviation & 0.2 & 0.3 \\
C.V. $(\%)$ & 2.7 & 3.0 \\
\hline
\end{tabular}

The distribution of the relative frequency of S. saponaria seeds length and width is shown in Figure 2. The seeds have an average length of $10.3 \mathrm{~mm}$ (ranging from 9.3 to $10.9 \mathrm{~mm}$ ) with a predominance of seeds with length between 10.2 and $10.4 \mathrm{~mm}$. The average seed width was $10.2 \mathrm{~mm}$ (ranging from 9.1 to $10.8 \mathrm{~mm}$ ), and $22 \%$ of these seeds predominate with a width of 10.2 to $10.4 \mathrm{~mm}$. There was an asymmetric behavior for the length and width of the seeds being classified as positive high asymmetry. 
According to Ferreira (2000), when the data are asymmetrical, both the right (positive asymmetry) and the left (negative asymmetry), the median is usually the best measure of central tendency. Since the average is sensitive to external observations, pushed towards the atypical values and may be excessively increased or reduced. In this study, the most important classes of seed length and seed width were used to evaluate the ecological aspects of the species (Macedo et al., 2009).

The $S$. saponaria (Figure 3A) is spherical, shiny black in color, with a rigid and smooth integument, in which the hilar region can be easily distinguished, surrounded by thin yellow whitish fur. This description is in accordance with that presented by Albiero et al. (2001), in his study on the anatomical characterization of the leaves, fruits and seeds of $S$. saponaria. The embryo is total, aclorophyllate, with crass cotyledons and hypocotyl-short radicle axis, yellow whitish color (Figure 3B).

A
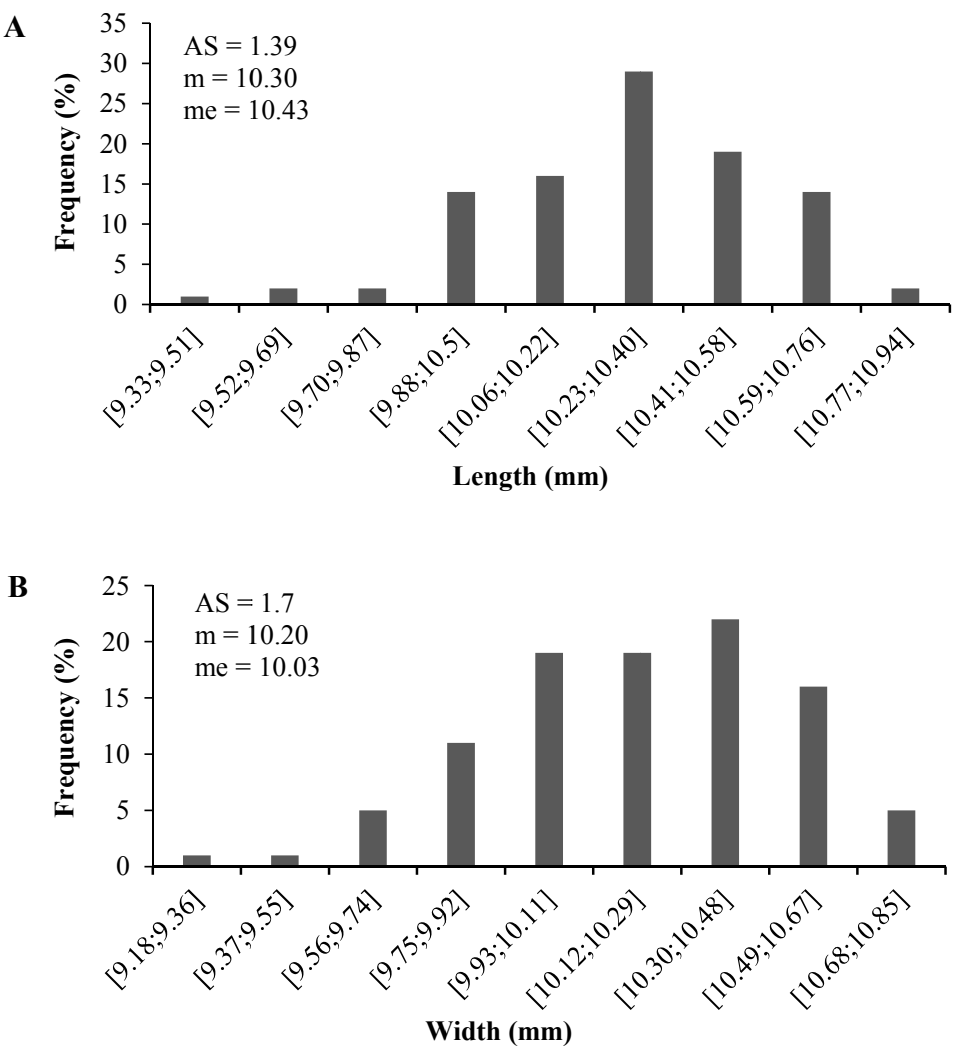

Figure 2. Distribution of the relative frequencies of length (A) and width (B) of Sapindus saponaria L. seeds $(\mathrm{AS}=$ asymmetry; $\mathrm{m}=$ average; $\mathrm{me}=$ median $)$

A

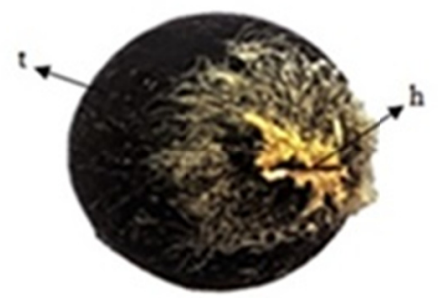

B

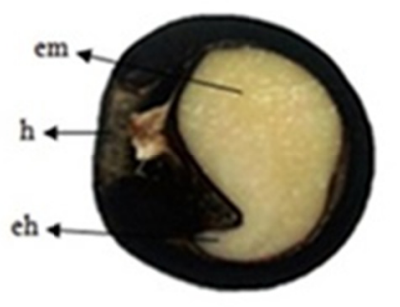

$\overline{1 \mathrm{~cm}}$

Figure 3. Morphological characterization of the Sapindus saponaria L. seed, external view of the seed (A), seed after longitudinal cut $(\mathrm{B}) .(\mathrm{h}=$ thread, $\mathrm{t}=$ integument, in $=$ embryo, and $\mathrm{h}=$ axis-hypocotyl-radicle) 
The weight of 1,000 seeds presented an average of $672.4 \mathrm{~g}$, corresponding to the approximate number of 1,487 seeds per kilogram (Table 2). These data are lower than those found by Lorenzi (1992) and Frigieri et al. (2016), where they mentioned a total of 1,870 and 1,545 units, respectively. Possibly, the explanation for the variation between the results can be related to the difference in the water content of the seeds, which is variable according to the season and harvest environment. According to Vaughton and Ramsey (1998), and Leishman et al. (2000), this change in the weight of the seeds within the plant itself may be related to the effects caused by changes in the environment during its formation.

According to Brazil (2009), the seeds are considered small when they present values above 5,000 units $\mathrm{kg}^{-1}$, and large, when lower. Thus, following this classification the seeds of $S$. saponaria can be considered large, since in one kilo it contains 1,487 units.

Table 2. Descriptive statistics of the weighing obtained to calculate the one thousand seeds of Sapindus saponaria L. weight

\begin{tabular}{ll}
\hline Statistical measures & Thousand seeds weight \\
\hline Average of repetitions $(\mathrm{g})$ & 67.2 \\
Variance $\left(\mathrm{s}^{2}\right)$ & 0.8 \\
Standard deviation $(\mathrm{s})$ & 0.9 \\
\hline C.V. $(\%)$ & 1.35 \\
\hline
\end{tabular}

The profiles of methyl esters of fatty acids obtained from the seeds of $S$. saponaria are present in Table 3. Oleic acid (C18:1) was predominant in the oil extracted from the seeds of $S$. saponaria, with 57.6\% of the following gadoleic acid (C20:1), linoleic (C18:2), eicosanoic (C20:0) palmitic (C16:0), lignoceric (C24:0), stearic (C18:0), linolenic $(\mathrm{C} 18: 3)$, behenic $(\mathrm{C} 22: 0)$, erucic $(\mathrm{C} 22: 1)$, palmitoleic $(\mathrm{C} 16: 1)$ and caprylic $(\mathrm{C} 8: 0)$, total quantification twelve fatty acids. The oil content was found to $7.25 \%$, most being composed of unsaturated fatty acids $(78.9 \%)$ and $21.1 \%$ saturated. Lovato et al. (2014) obtained similar results when quantifying the oil S. saponaria, where the oleic acid was the most abundant, with about 52.45\%. Also according to these authors, it was possible to quantify a total of seven fatty acids, being $57.60 \%$ of unsaturated and saturated $42.40 \%$.

The quality of oil is given by its fatty acid composition and its various stability according to the percentage of the predominant fatty acid in this, which indicates whether or not the use of antioxidants against seed storage.

Table 3. Fatty acid profiles obtained from oil seeds of Sapindus saponaria L.

\begin{tabular}{lll}
\hline Fatty Acid & Representation & Percentage $\%$ \\
\hline Caprylic & $\mathrm{C} 8: 0$ & 0.2 \\
Palmitic & $\mathrm{C} 16: 0$ & 6.5 \\
Palmitoleic & $\mathrm{C} 16: 1$ & 0.2 \\
Stearic & $\mathrm{C} 18: 0$ & 2.4 \\
Oleic & $\mathrm{C} 18: 1$ & 57.6 \\
Linoleic & $\mathrm{C} 18: 2$ & 8.1 \\
Linoleic & $\mathrm{C} 18: 3$ & 1.6 \\
Eicosanoic & $\mathrm{C} 20: 0$ & 8.1 \\
Gadoleic & $\mathrm{C} 20: 1$ & 10.9 \\
Behenic & $\mathrm{C} 22: 0$ & 0.9 \\
Erucic & $\mathrm{C} 22: 1$ & 0.5 \\
Lignoceric & $\mathrm{C} 24: 0$ & 3.0 \\
\hline
\end{tabular}

The oxidative stability of oils tends to be lower with the increase of polyunsaturated compounds such as linoleic and linolenic acids, being susceptible to auto-oxidation. Thus, high levels of linoleic and linolenic acid resulted in a higher oxidation rate of 64 to 100 times higher, respectively, than the oxidation of oleic acid (Oetterer et al., 2006; Ramos et al., 2009). It is noteworthy that changes in oil quality can be realized by changing the proportion of the fatty acids, these in turn are strongly influenced by ambient conditions, particularly temperature during seed development. Oliveira and Vieira (2004) reported that higher temperatures provide increased levels of oleic 
acid and reduced levels of linoleic acid. In species Sapindus mukorossi represented oleic acid $62.8 \%$ (Sengupta et al., 1975).

According to Santos et al. (2010) the Sapindaceae family stands out for presenting seeds with potential for oil production, as well as differences in their fatty acid composition. In this study, the oil content found in $S$. saponaria seeds was $7.25 \%$, which was low compared to other species of the same family as was the case of the species Magonia pubescens, Paullinea sp. and Dilodendron bipinnatum studied by Nunes (2012), showed that high levels of oil above $25 \%$ were considered potentially promising for biofuel production due to a higher proportion of monoinsatirados fatty acids in the composition.

\subsection{Post-seminal Seedlings Development}

The first visible signs of germination began four days after sowing, with tegument rupture, evidencing the hood (Figure 4A). At fifth days (Figure 4B), the protrusion of the primary root, which was $0.6 \mathrm{~cm}$ long and whitish in color, occurred mainly in the region of the hood. Seven days after sowing (Figure 4C), the elongation of the primary root was observed with a slight change in the color of the epidermis, becoming less whitish, measuring around $1.2 \mathrm{~cm}$, with the slow and gradual appearance of the eophils (first distinct leaves of adult leaves), light green in color. Structural variations in the post-seminal phase, among them, heterofilia is a common factor in the seedling phase in forest species, where the first leaves (eophiles) may present distinct morphology of the adult leaves (Montoro, 2008).

With the elongation of the primary root (Figure 4D), nine days after sowing, it was possible to observe the beginning of the appearance of the first secondary root and the change in coloration of the primary root, from whitish to cream; the eophiles appeared totally free of the integument, green, delicate and opposite. Seeds with eophiles totally free from the integument were considered germinated.

On the thirteenth day after sowing (Figure 4E), the rapid development of epicotyl and root system was observed. The primary root was initially thick, becoming thinner with development. At this stage, seedlings had few secondary roots and a root system classified as pivoting, measuring approximately $4.6 \mathrm{~cm}$ in length. The epicotyl was, however, elongated with an average of $5.3 \mathrm{~cm}$. At the end of the trial, thirty days after sowing (Figure 4F), the seedlings presented with all their essential structures formed and developed, measuring on average $11.3 \mathrm{~cm}$ in length in total. The seed germination presented the cryptocotiledonar-hypogean type.

In the classification of seedlings of different angiosperms species, the seed attributes (size, function, position of the cotyledons and reserve material) are directly related to the initial morphology of the seedlings, characterizing the morpho-functional types (Garwood, 1996; Pereira et al. al., 2008). For Hladik and Miquel (1990) postseminal development is characterized by five types of seedlings: phanero-colony-epigeal with foliaceous cotyledons (PEF); (PHR), cryptocotiledonar/hygegea with reserve cotyledons (CHR) and cryptocotiledonarepigeal with reserve cotyledons (CER), which result from the functional adaptation of the phytocotiledonarepígea with reserve cotyledons (PER) to the environment, associated to ecological factors, such as seed dispersal capacity and regeneration strategy (Garwood, 1996; Ibarra-Manríquez et al., 2001).

Some types of S. saponaria plantlet abnormalities (Figure 5) were observed, such as congenital malformation on early onset, stunted eophytes, atrophied roots and epicotyls, and abnormality at the main root. There was also the occurrence of fungus-infested seedlings throughout the trials (Figure 6). However, infested seedlings continued their development without apparent damage throughout the germination test (30 days). 

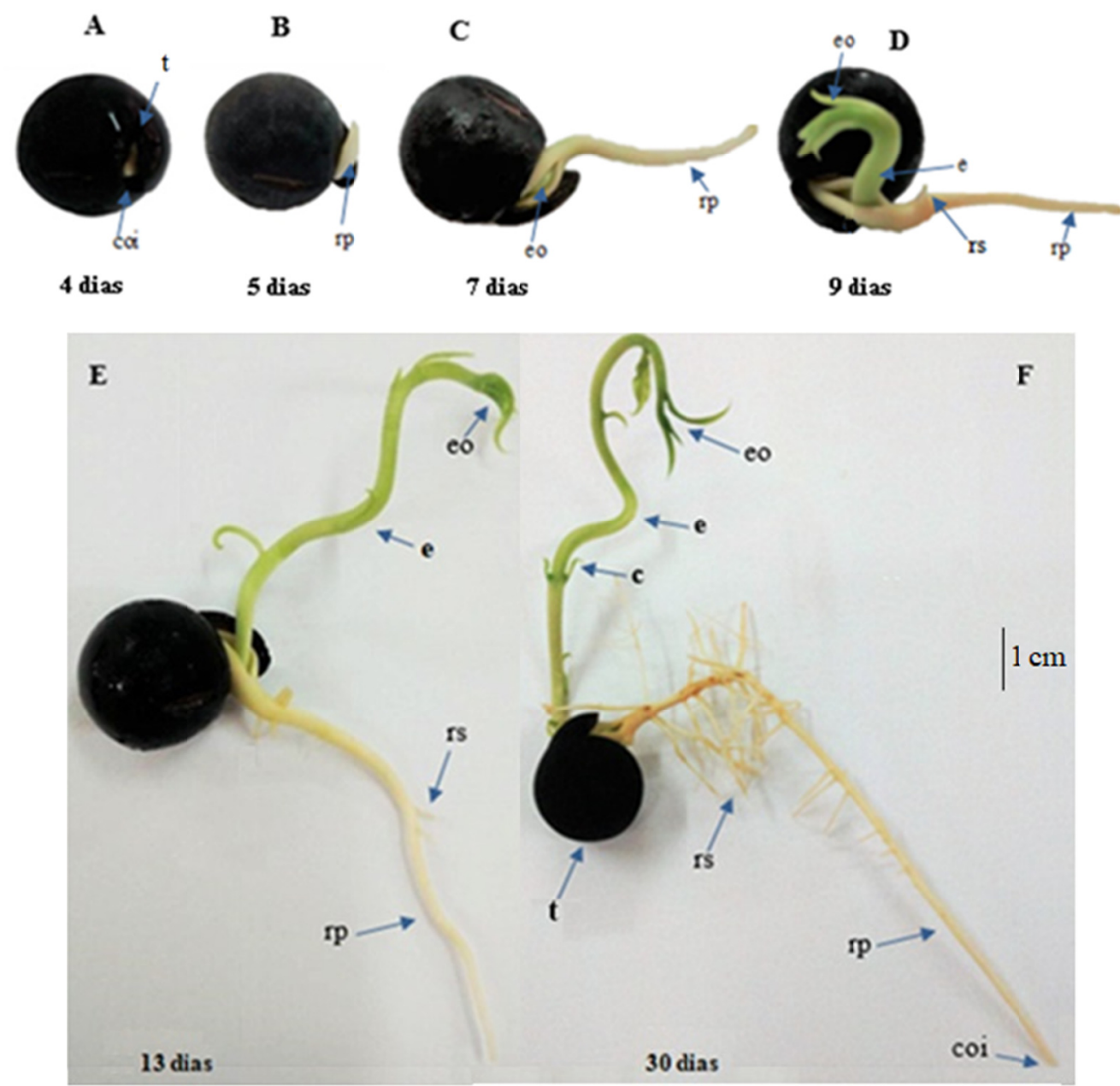

Figure 4. Successive stages of Sapindus saponaria L., with four (A), five (B), seven (C), nine (D), thirteen (E) and thirty $(\mathrm{F})$ days after sowing. $(\mathrm{c}=$ cataphyll, $\mathrm{co}=$ cotyledons, $\mathrm{coi}=$ coif, $\mathrm{e}=$ epicotyl, $\mathrm{eo}=$ eophile, $\mathrm{rp}=$ primary root, $\mathrm{rs}=$ secondary root, $\mathrm{t}=$ tegument)

A

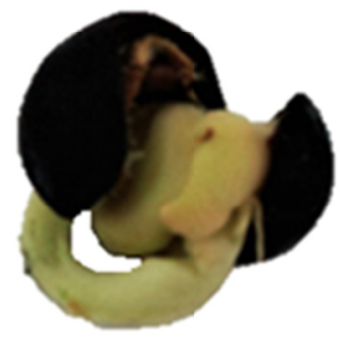

B

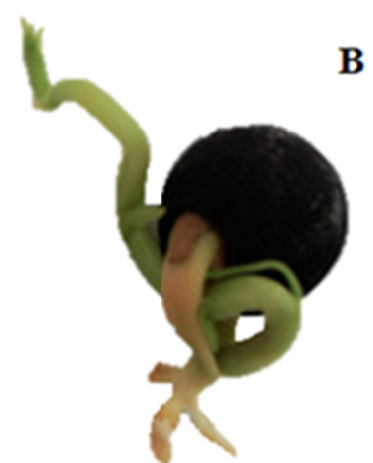

C

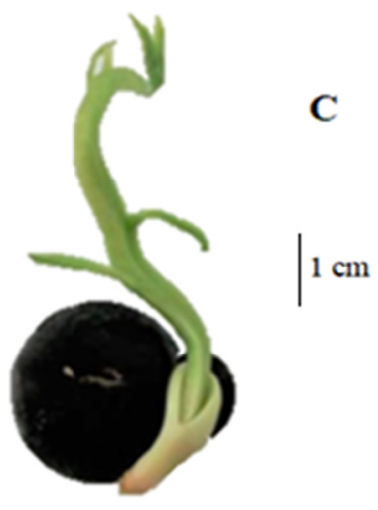

Figure 5. Sapindus saponaria L. abnormal seedlings. A = poor seedling formation, with atrophy; B = stunted eophiles, atrophied roots and epicotyl; $\mathrm{C}=$ seedling with abnormality at the main root 


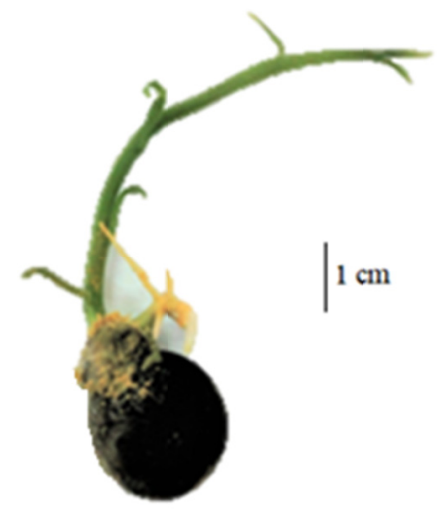

Figure 6. Sapindus saponaria L. seedling, infested with fungus

\subsection{Pre-germination Treatments for Seed Dormancy Overcoming}

The highest values of germination and GRI were obtained when seeds were immersed in sulfuric acid for 30 minutes, with values of $72 \%$ and 1.7 , respectively (Table 4 ). This increase was probably caused by the action of sulfuric acid in the softening of the seed coat, acting on the removal of the cuticle, with consequent exposure of the macroscleride layers, providing more homogeneous degrees of permeability (Santarém \& Áquila, 1995).

Table 4. Germination (G) and germination rate index (GRI) of Sapindus saponaria L. seeds, submitted to different treatments of dormancy overcoming

\begin{tabular}{|c|c|c|}
\hline Treatments & G (\%) & GRI \\
\hline Control & $40 \mathrm{BC}$ & $0.5 \mathrm{D}$ \\
\hline Mechanical scarification (sandpaper $n^{\circ} 6$ ) & $52 \mathrm{ABC}$ & $0.9 \mathrm{BCD}$ \\
\hline Chemical scarification (sulfuric acid for $5 \mathrm{~min}$ ) & $38 \mathrm{C}$ & $0.6 \mathrm{D}$ \\
\hline Chemical scarification (sulfuric acid for $10 \mathrm{~min}$ ) & $52 \mathrm{ABC}$ & $1.0 \mathrm{BCD}$ \\
\hline Chemical scarification (sulfuric acid for $20 \mathrm{~min}$ ) & $62 \mathrm{AB}$ & $1.2 \mathrm{ABC}$ \\
\hline Chemical scarification (sulfuric acid for $30 \mathrm{~min}$ ) & $72 \mathrm{~A}$ & $1.7 \mathrm{~A}$ \\
\hline Chemical scarification (sulfuric acid for $40 \mathrm{~min}$ ) & $62 \mathrm{AB}$ & $1.3 \mathrm{AB}$ \\
\hline Immersion in distilled water for 24 hours & $46 \mathrm{BC}$ & $0.7 \mathrm{CD}$ \\
\hline Immersion in hot water $\left(80^{\circ} \mathrm{C}\right)$ to ambient temperature & $40 \mathrm{BC}$ & $0.5 \mathrm{D}$ \\
\hline "F" value for dormancy treatment & $5.9 * *$ & $11 ., 9 * *$ \\
\hline C.V. $(\%)$ & 18.2 & 23.4 \\
\hline
\end{tabular}

Note. ns: not significant; * significant at $5 \%$ by the F-test.

Albiero et al. (2001) observed in an anatomical study of the tegument of the saponaria seeds, that these have double tegument, with many layers of cells in the forehead, being the exotesta formed by macroescleids, the sclerotic mesotesta and the apparently fibrous endotesta, with parenchymic tegmem constituted by approximately 13 layers of wall cells, characterizing the dormancy imposed by the impermeability of the integument, which constitutes a barrier to the water absorption by the seeds. Thus, as the seed coat of $S$. saponaria is thick and fairly scleridified, it is justified the need for a prolonged period of exposition of the same in sulfuric acid to overcome dormancy. It is also worth noting that the efficacy of this method depends on some factors such as the exposure time to sulfuric acid and the age of the seeds (Albuquerque et al., 2009).

Seeds of $S$. saponaria when immersed in sulfuric acid for 40 minutes showed a decrease in percentage values and germination rate index (Table 3). For Santos et al. (2014) the corrosive effect of this compound can promote irreversible injuries to the embryo, which may explain the decrease in the germination of the seeds submitted to this treatment. Contradictory results were found by Oliveira et al. (2012), who stated that the immersion of $S$. saponaria seeds in sulfuric acid for 60 minutes was able to promote the overcoming of seed dormancy, however in this study the concentration of sulfuric acid used was not specified, which may justify the favorable germinative performance over the long period of immersion (60 minutes). 
When mechanically scarified, the seeds of $S$. saponaria showed little more than $50 \%$ germination (Table 3 ). A relatively expressive result, but not indicated for the species, due to the difficulty of manual scarification caused by stiffness of the tegument, as observed by Albiero et al. (2001).

Although mechanical scarification is also widely used as an efficient treatment to overcome the integumentary dormancy of many seeds, it requires manpower and availability of time and is indicated for small seed lots. For larger plots, this scarification could be mechanized, but it is necessary to pay scarification uniformity level, which can result in significant losses, especially for species with production irregular, as well as those that rapidly lose their viability (Aguiar, 1995; Bortolini et al., 2016).

Faria and Davide (1991) reported that the integumentary dormancy presented by S. saponaria seeds can be overcome by scarification with sandpaper No. 60 for 30 seconds, although handling with sulfuric acid is dangerous, this treatment is considered more practical when for cases with large seed lots, where their use may be a viable alternative in terms of research with this species (Oliveira et al., 2003).

For germination time average (GTA) (Table 5), there was no statistical difference between the control and pre-germinated seeds treated. Higher values of germination velocity average (GVA) were observed in the treatments: immersion in sulfuric acid for 30 and 40 minutes, with 0.073 and 0.070 days $^{-1}$. Treatments with lower GVA values indicate that germination was slow and at longer time intervals.

Table 5. Germination time average (GTA) and germination velocity average (GVA) of Sapindus saponaria L. seeds, at different treatments of dormancy overcoming

\begin{tabular}{|c|c|c|}
\hline Treatments & GTA & GVA \\
\hline Control & $19.6 \mathrm{~A}$ & $0.050 \mathrm{AB}$ \\
\hline Mechanical scarification (sandpaper $n^{\circ} 6$ ) & $16.9 \mathrm{~A}$ & $0.060 \mathrm{AB}$ \\
\hline Chemical scarification (sulfuric acid for $5 \mathrm{~min}$ ) & $14.9 \mathrm{~A}$ & $0.045 \mathrm{~B}$ \\
\hline Chemical scarification (sulfuric acid for $10 \mathrm{~min}$ ) & $16.6 \mathrm{~A}$ & $0.060 \mathrm{AB}$ \\
\hline Chemical scarification (sulfuric acid for $20 \mathrm{~min}$ ) & $16.4 \mathrm{~A}$ & $0.061 \mathrm{AB}$ \\
\hline Chemical scarification (sulfuric acid for $30 \mathrm{~min}$ ) & $13.6 \mathrm{~A}$ & $0.073 \mathrm{~A}$ \\
\hline Chemical scarification (sulfuric acid for $40 \mathrm{~min}$ ) & $14.4 \mathrm{~A}$ & $0.070 \mathrm{~A}$ \\
\hline Immersion in distilled water for 24 hours & $17.3 \mathrm{~A}$ & $0.058 \mathrm{AB}$ \\
\hline Immersion in hot water $\left(80^{\circ} \mathrm{C}\right)$ to ambient temperature & $18.9 \mathrm{~A}$ & $0.052 \mathrm{AB}$ \\
\hline "F" value for dormancy treatment & $1.5^{\mathrm{N} \bar{S}^{-1}}$ & $3.0^{*}$ \\
\hline C.V. $(\%)$ & 14.5 & 18.3 \\
\hline
\end{tabular}

Note. ns: not significant; ${ }^{*}$ significant at $5 \%$ by the F-test.

Regarding the uncertainty and synchrony results (Table 6), a high degree of uncertainty and low synchrony were observed, with the germination distributed in the medium time. According to Santana et al. (2010), when the uncertainty values are above zero $(U>1.80)$ and $Z$ close to zero $(Z<0.32)$ means that the germination and seed emergence processes are spread in relation to the medium time, with a high degree of uncertainty and low synchrony. These authors obtained similar results, when they studied the germination of Pau-santo (Kielmeyera coriacea), with high degree of uncertainty, low synchrony and germination distribution in relation to the mean time. 
Table 6. Synchrony of germination (Z) and uncertainty of germination (U) of Sapindus saponaria L. seeds, to different dormancy overcoming treatments

\begin{tabular}{|c|c|c|}
\hline Treatments & $\mathrm{Z}$ & $\mathrm{U}$ \\
\hline Control & $0.077 \mathrm{AB}$ & $2.652 \mathrm{~A}$ \\
\hline Mechanical scarification (sandpaper $\mathrm{n}^{\circ} 6$ ) & $0.130 \mathrm{AB}$ & $2.585 \mathrm{~A}$ \\
\hline Chemical scarification (sulfuric acid for $5 \mathrm{~min}$ ) & $0.054 \mathrm{~B}$ & $2.262 \mathrm{~A}$ \\
\hline Chemical scarification (sulfuric acid for $10 \mathrm{~min}$ ) & $0.068 \mathrm{AB}$ & $3.099 \mathrm{~A}$ \\
\hline Chemical scarification (sulfuric acid for $20 \mathrm{~min}$ ) & $0.073 \mathrm{AB}$ & $3.142 \mathrm{~A}$ \\
\hline Chemical scarification (sulfuric acid for $30 \mathrm{~min}$ ) & $0.105 \mathrm{AB}$ & $2.920 \mathrm{~A}$ \\
\hline Chemical scarification (sulfuric acid for $40 \mathrm{~min}$ ) & $0.144 \mathrm{~A}$ & $2.553 \mathrm{~A}$ \\
\hline Immersion in distilled water for 24 hours & $0.083 \mathrm{AB}$ & $2.812 \mathrm{~A}$ \\
\hline Immersion in hot water $\left(80^{\circ} \mathrm{C}\right)$ to ambient temperature & $0.084 \mathrm{AB}$ & $2.614 \mathrm{~A}$ \\
\hline "F" value for dormancy treatment & $3.2^{*}$ & $0.9^{\mathrm{N}^{-1}}$ \\
\hline C.V. $(\%)$ & 20.0 & 21.5 \\
\hline
\end{tabular}

Note. ns: not significant; * significant at $5 \%$ by the F-test.

The synchrony, uncertainty, time and germination speed average are aspects that can be calculated, and which demonstrate the dynamics of the germination process. Considered important characteristics not only for physiologists and seed technologists, but also for ecologists, precisely for the ability to predict the degree of success of the species, based on the ability of the seed crop to distribute germination over time (Ranal \& Santana, 2006)

\section{Conclusions}

The seeds of $S$. saponaria present on average $10.3 \mathrm{~mm}$ in length and $10.2 \mathrm{~mm}$ in width, germination of the cryptocoyledonar-hypogean type, with higher values of percentage of germination when the seeds are immersed in sulfuric acid for 30 minutes.

\section{References}

Aguiar, I. B. (1995). Conservação de sementes. In A. Silva, F. C. M. Pina-Rodrigues, \& M. B. Figliolia (Eds.), Manual técnico de sementes florestais. São Paulo, SP: Instituto Florestal.

Albiero, A. L. M., Bacchi, E. M., \& Mourão, K. S. M. (2001). Caracterização anatômica das folhas, frutos e sementes de Sapindus saponaria L. (Sapindaceae). Acta Sci., 23(2), 49-56. https://doi.org/10.4025/ actascibiolsci.v23i0.2733

Albuquerque, K. S., Guimarães, R. M., Almeida, I. D., \& Clemente, A. D. C. S. (2009). Alterações fisiológicas e bioquímicas durante a embebição de sementes de sucupira-preta (Bowdichia virgilioides Kunth.). Rev. Bras. Sementes, 31(1), 12-19. https://doi.org/10.1590/S0101-31222009000100028

Bortolini, M. F., Koehler, H. S., Zuffellato-Ribas, K. C., \& Fortes, A. M. T. (2016). Crescimento de mudas de Cupania vernalis produzidas sob diferentes substratos. Cientifica, 44(4), 599-607. https://doi.org/10.15361/ 1984-5529.2016v44n4p599-607

Brasil. (2009). Regras para análise de sementes. Ministério da Agricultura, Pecuária e Abastecimento, Secretaria de Defesa Agropecuária. Brasília: DF: Mapa.

Camara, C. A., Araujo Neto, J. C., Ferreira, V. M., Resende, L. P., \& Costa, S. S. (2009). Características morfométricas de frutos e sementes e germinação de Thespesia populnea. Bragantia, 68(2), 503-509. https://doi.org/10.1590/S0006-87052009000200025

Cruz, D. F., Martins, P. O., \& Carvalho, J. E. U. (2011). Biometria de frutos e sementes e germinação de jatobá-curuba (Hymenaea intermedia Ducke, Leguminosae-Caesalpinioideae). Rev. Bras. Botânica, 24(2), 161-165. https://doi.org/10.1590/S0100-84042001000200005

Faria, J., \& Davide, A. (1991). Quebra de dormência em sementes de saboneteira (Sapindus saponaria L.-Sapindaceae). Informativo ABRATES, Brasília, 1(4), 82.

Ferreira, P. V. (2000). Estatística experimental aplicada à agronomia (3th ed.). Maceió, AL: Edufal.

Frigieri, F. F., Iwanicki, N. S. A., Gandara, F. B., Ferraz, E. M., Romão, G. O., Coletti, G. F., ... Moreno, M. A. (2016). Guia de plântulas e sementes da Mata Atlântica do estado de São Paulo. Piracicaba, SP: IPEF. 
Garwood, N. C. (1996). Functional morphology of tropical tree seedlings. In M. D. Swaine (Ed.), The ecology of tropical forest tree seedlings. Paris: Man and the Biosphere series.

Gusmão, E., Vieira, F. A., \& Fonseca, E. M. (2006). Biometria de frutos e endocarpos de murici (Byrsonma verbascifolia Rich. Ex. A. Juss.). Cerne, 12(1), 84-91, 2006.

Hladik, A., \& Miquel, S. (1990). Seedling types and plant establishment in an African rain forest. In K. S. Bawa, $\&$ M. Hadley (Eds.), Reproductive ecology of tropical forest plants. Paris, Man and the Biosphere series.

Ibarra-Manríquez, G., Ramos, M. M., \& Oyama, K. (2001). Seedling functional types in a lowland rain forest in Mexico. Am. J. Bot., 88(10), 1801-1812. https://doi.org/10.2307/3558356

Judd, W. S., Campbell, C. S., Kellogg, E. A., Stevens, P. F., \& Donoghue, M. J. (2009). Sistemática Vegetal: Um Enfoque Filogenético (3th ed.). Porto Alegre, RS: Artmed.

Ladeira, H. P. (2002). Quatro décadas de Engenharia Florestal no Brasil. Viçosa, MG: Sociedade de Investigações Florestais.

Leishman, M. R., Wright, I. J., Moles, A. T., \& Westoby, M. (2000). The evolutionary ecology of seed size. In M. Fenner (Ed.), Seeds-The ecology of regeneration in plant communities. Wallingford, CAB International. https://doi.org/10.1079/9780851994321.0031

Lorenzi, H. (1992). Árvores brasileiras: Manual de identificação e cultivo de plantas arbóreas nativas do Brasil. Nova Odessa, SP: Editora Plantarum.

Lovato, L., Pelegrini, B. L., Rodrigues, J., Oliveira, A. J. B., \& Ferreira, I. C. P. (2014). Seed oil of Sapindus saponaria L. (Sapindaceae) as potential C16 to C22 Fatty acids resource. Biomass Bioenergy, 60, 247-251. https://doi.org/10.1016/j.biombioe.2013.11.016

Macedo, M. C., Scalon, S. P. Q., Sari, A. P., Scalon Filho, H., Rosa, Y. B. C. J., \& Robaiana, A. D. (2009). Biometria de frutos e sementes e germinação de Magonia pubescens ST. Hil (Sapindaceae). Rev. Bras. Sementes, 31(2), 202-211. https://doi.org/10.1590/S0101-31222009000200024

Matheus, M. T., \& Lopes, J. C. (2007). Morfologia de frutos, sementes e plântulas e germinação de sementes de Erythrina variegata L. Rev. Bras. Sementes, 29(3) 08-17. https://doi.org/10.1590/S0101-312220070 00300002

Melo, L. D. F. A., Gonçalves, E. P., Ralph, L. N., Viana, J. S., \& Silva, S. C. A. (2015). Physiological and physical quality of seeds from peanut seeds and plants under the Influence of fertilizer and biostimulant. $\mathrm{Am}$. J. Plant Sci., 6(2), 1594-1606. https://doi.org/10.4236/ajps.2015.69160

Mena Valdés, L., Tamargo Santos, B., Salas Olivet, E., Plaza Paredes, L. E., Blanco Hernández, Y., Otero González, A., \& Sierra González, G. (2015). Determinación de saponinas y otros metabolitos secundarios en extractos acuosos de Sapindus saponaria L. (jaboncillo). Rev. Cubana Plant Med., 20(1), 106-116.

Montoro, G. R. (2008). Morfologia de plântulas de quatorze espécies lenhosas do Cerrado sentido restrito (Dissertação (Mestrado em Botânica), Instituto de Ciências Biólogicas, Universidade de Brasília, Brasília).

Nunes, M. S. (2012). Plantas do semi-árido baiano para produção de biodiesel (Thesis, Universidade Estadual de Feira de Santana, Brasil).

Oetterer, M., Regitano-D’Arce, M. A. B., \& Spoto, M. H. F. (2006). Fundamentos de ciência e tecnologia de alimentos. Barueri, SP: Manole.

Oliveira, E. C. (1993). Morfologia de Plântulas. In I. B. Aguiar, F. C. M. Piña-Rodrigues, \& M. B. Figliola (Eds.), Sementes Florestais Tropicais. Brasília: ABRATES.

Oliveira, J. S., Leite, P. M., Souza, L. B., Mello, V. M., Silva, E. C., Rubim, J. C., ... Suarez, P. A. Z. (2009). Characteristics and composition of Jatropha gossypiifolia and Jatropha curcas L. oils and application for biodiesel production. Biomass and Bioenergy, 33(3), 449-453. https://doi.org/10.1016/j.biombioe.2008. 08.006

Oliveira, L. M., Bruno, R. L. A., Silva, K. R. G., Silva, V. D. M., Ferrari, C. S., \& Silva, G. Z. (2012). Germinação e vigor de sementes de Sapindus saponaria L. submetidas a tratamentos pré-germinativos, temperaturas e substratos. Ciência Rural, 42(4) 638-644. https://doi.org/10.1590/S0103-847820120 00400010 
Oliveira, L. M., Davide, A. C., \& de Carvalho, M. L. M. (2003). Avaliação de métodos para quebra da dormência e para a desinfestação de sementes de canafístula (Peltophorum dubium (Sprengel) Taubert1). Rev. Árvore, 27(5). 597-603. https://doi.org/10.1590/S0100-67622003000500001

Oliveira, M. F., \& Vieira, O. V. (2014). Extração de óleo de girassol utilizando miniprensa. Documentos Embrapa.

Pelegrini, D. D., Tsuzuki, J. K., Amado, C. A., Cortez, D. A., \& Ferreira, I. C. (2008). Biological activity and isolated compounds in Sapindus saponaria L. and other plants of the genus Sapindus. Lat. Am. J. Pharm., 27(6), 922-927.

Pereira, A. R., Pereira, T. S., Rodrigues, A. S., \& Andrade, A. C. S. D. (2008). Morfologia de sementes e do desenvolvimento pós-seminal de espécies de Bromeliaceae. Acta Bot. Bras., 22(4), 1150-1162. https://doi.org/10.1590/S0102-33062008000400026

Persons, W. M. (1910). The correlation of economic statistics. Publications of American Statistical Association, 12(92), 287-322. https://doi.org/10.2307/2964825

Pio-Correa, M. (1984). Dicionário das plantas úteis e das exóticas cultivadas. Rio de Janeiro: Ministério da Agricultara Serviço de Informação.

Previero, C. A., Lima Júnior, B. C., Florencio, L. K., \& Santos, D. L. (2010). Receitas de plantas com propriedades inseticidas no controle de pragas. Palmas: CEULP/ULBRA.

Ramos, M. J., Fernández, C. M., Casas, A., Rodríguez, L., \& Pérez, Á. (2009). Influence of fatty acid composition of raw materialson biodiesel properties. Bioresource Technology, 100(1), 261-268. https://doi.org/10.1016/j.biortech.2008.06.039

Ranal, M. A., \& Santana, D. G. (2006). How and why to measure the germination process? Rev. Bras. Botânica, 29(1), 1-11. https://doi.org/10.1590/S0100-84042006000100002

Ribeiro, J. E. L. S., Hopkins, A., Vicentini, C. A., Sothers, M. A. S., Costa, J. M., Brito, M. A. D., ... Procópio, L. C. (1999). Flora da Reserva Ducke: Guia de identificação das plantas vasculares de uma floresta de terra-firme na Amazônia Central. Manaus, AM: INPA-DFID.

Rodrigues, A. C. C., Osuna, J. T. A., Queiroz, S. R. O. D., \& Rios, A. P. (2006). Biometria de frutos e sementes e grau de umidade de sementes de angico (Anadenanthera colubrina (vell.) Brenan var. cebil (griseb.) Altschul) procedentes de duas áreas distintas. Rev. Cient Elet Engenh Florestal, 4(8), 1-15.

Santana, D. G., Anastácio, M. R., Lima, J. A. E., \& Mattos, M. B. (2010). Germinação de sementes e emergência de plântulas de pau-santo: uma análise crítica do uso de correlação. Rev. Bras. Sementes, 32, 134-140. https://doi.org/10.1590/S0101-31222010000300015

Santarém, E. R., \& Áquila, M. E. A. (1995). Influência de métodos de superação de dormência e do armazenamento na germinação de sementes de Senna macranthera (Colladon) Irwin e Barneby (Leguminosae). Rev. Bras. Sementes, 17(2), 205-209. https://doi.org/10.17801/0101-3122/rbs.v17n2 p205-209

Santos, A. C. A., Rossato, M., Atti Serafini, L., Bueno, M., Crippa, L. B., \& Sartori, V. C. (2010). Efeito fungicida dos óleos essenciais de Schinus molle L. e Schinus terebinthifolius Raddi, Anacardiaceae, do Rio Grande do Sul. Brazilian Journal of Pharmacognosy, 20(2), 154-159. https://doi.org/10.1590/S0102-695X 2010000200003

Santos, J. L., Luz, I. S., Matsumoto, S. N., D’Arêde, L. O., \& Viana, A. E. S. (2014). Superação da dormência tegumentar de sementes de Piptadenia viridiflora (Kunth) Benth pela escarificação química. Biosc. J., 30(6), $1642-1651$.

Sarmento, M. B., \& Villela, F. A. (2010). Sementes florestais nativas do Brasil. A Revista Internacional de Sementes, 4(1), 34-37.

Sengupta, A., Basu, S. P., \& Saha, S. (1975). Triglyceride composition of Sapindus mukorossi seed oil. Lipids, Champaign, 10, 33-40. https://doi.org/10.1007/BF02532191

Souza, V. C., \& Lorenzi, H. (2012). Botânica sistemática: Guia ilustrado para a identificação das famílias de Fanerógamas nativas e exóticas no Brasil, baseado em APG III (3rd ed.). Nova Odessa: Instituto Plantarum. 
Vaughton, G., \& Ramsey, M. (1998). Sources and consequences of seed mass variation in Banksia marginata (Proteaceae). Journal of Ecology, 86(1), 563-573. https://doi.org/10.1046/j.1365-2745.1998.00279.x

Virgens, A. P., Freitas, L. C., \& Leite, A. M. P. (2016). Economic and sensitivity analysis in a settlement stablished in Southwestern Bahia. Floresta e Ambiente, 23(2), 211-219. https://doi.org/10.1590/2179-8087. 104914

\section{Copyrights}

Copyright for this article is retained by the author(s), with first publication rights granted to the journal.

This is an open-access article distributed under the terms and conditions of the Creative Commons Attribution license (http://creativecommons.org/licenses/by/4.0/). 